\title{
On Elaioplasts.
}

\author{
BY \\ RUDOLF BEER, B.SC, F.L.S.
}

With Plate IV.

IN I 888 Wakker (1) described the occurrence of a conspicuous body lying 1 in the epidermal cells of the leaves and in the superficial tissues of the root and stem of Vanilla planifolia. This body is somewhat larger than the nucleus and considerably larger than the amyloplasts; it possesses a sharply-defined outline and a peculiar, somewhat yellowish colour. In each plate-like epidermal cell one such body occurs, and it often lies near the nucleus, although in other cases it may occupy a different position in the cell. As this body consists of protoplasmic material and contains oil, Wakker named it Elaioplast, or oil-former.

He made a careful study of the effect of reagents upon the elaioplast, and briefly described the gradual disappearance of these bodies in older cells. Wakker was unable to study the origin of the elaioplasts as he had no suitable material for this purpose. He found elaioplasts also to occur in the cells of another species of Vanilla, known to him under the name of Vanilla aromatica latifolia. In I 893 Zimmermann (2) found similar bodies to occur in Funkia coerulia, F. lancifolia, F. Sieboldiana, Dracaena sp., Ornithogahum scilloides, Agave americana, A. Mitis, and in Oncidium suave.

Raciborski (3) in the same year described elaioplasts in the tissues of various species of Ornithogalum, Albuca, Funkia, and Gagea.

Zimmermann further found these bodies in the internal cells of the stem of Psilotum, and in the perianth leaves of Maxillaria picta. The shape of the elaioplasts differs in various plants, but it is usually constant in the same species. Spherical forms, grape-like bodies, irregular plasmodium-like masses, have all been described.

Usually only one elaioplast occurs in a cell, but in some cases they may be more numerous (e.g. Ornithogalum). The finer structure of the elaioplast has been carefully examined both by Zimmermann and by Raciborski. It has a finely granular appearance due to the occurrence of a number of tiny, highly refractive spherical bodies lying in its substance. One or more less refractive spots often occur within the elaioplast. The elaioplasts of

[Annals of Botany, Vo1. XXIII. No. LXXXIX. January, 1909.] 
the species of Gagea are said by Raciborski to possess a somewhat different structure. In these plants the spherical elaioplasts are characterized by the feeble development of the stroma; they are surrounded by a plasmatic envelope and contain within this an oily substance like that found in other elaioplasts. The micro-chemical observations of Wakker and Zimmermann have shown that the elaioplasts consist of a plasmatic matrix or stroma in which are embedded numerous minute oil drops. Zimmermann points out that these oil drops show a close similarity in their reactions with the oil drops obtained from plastids.

The origin of the elaioplasts has been very little studied. Raciborski states that in Ornithogalum umbellatum they arise as small, highly refractive spherules which always lie at one pole of the usually elongated cell-nucleus.

Although Wakker had no material with which to work out the development of the elaioplast, he ventures an interesting suggestion at the conclusion of his account of the oil-bodies of liverworts. 'Leider ist durch diese Mittheilung der Ursprung der Elaioplasten nicht ausgemacht, es ist mir aber äusserst wahrscheinlich, dass es bei den Lebermoosen metamorphosirte Chlorophyllkörner sind. Vielleicht ist dieses auch bei Vanilla der Fall.'

Garjeanne's work (5) on the oil-bodies of the Jungermanniales clearly indicates that these bodies have a different origin to that suggested by Wakker; my own observations on elaioplasts recorded below will, however, show that his guess was nearer the truth in the case of some Phanerogamic elaioplasts.

The function of the elaioplast is quite unknown. Wakker believed that they might be oil-formers much as leucoplasts are starch-formers. Zimmermann offered the suggestion that they might prove to be parasitic or symbiotic fungi living within the cells of the higher plant.

Raciborski, however, considers them to be normal organs of the cell in which they occur, and classes them with oil-bodies, tannin-vesicles, and ordinary vacuoles.

In the liverworts oil-bodies have been known to occur since the time of Gottsche, and even earlier. The first really fundamental description of these bodies is due to Pfeffer (4), and quite recently their development has been fully worked out by Garjeanne (5). Oil or fat bodies of a somewhat similar appearance to those of the liverworts have been described by Radlkofer (6 and 7), Monteverde (8), Solereder (9), and others, in the tissues of a number of Dicotyledons and Monocotyledons. Opinion varies very much as to the relation of these oil-bodies of liverworts and Phanerogams to the elaioplasts. Some believe the two structures to be closely allied, whilst others are of opinion that they are radically different from one another.

From this brief survey of the literature it will be seen that elaioplasts, 
corresponding to those discovered by Wakker in Vanilla, have up to the present been found only in Monocotyledons, with the single exception of Psilotum reported by Zimmermann.

Moreover, apart from a few quite insufficient observations we are still entirely in the dark regarding their true nature, their significance, their origin, and their fate.

During some observations upon the pollen-grains of Compositae I was interested to find bodies which resembled the Monocotyledonous elaioplasts occurring in the tissues of the floral region of Gaillardia Lorenziana ${ }^{1}$.

This would extend the distribution of elaioplasts to a member of the Dicotyledons.

My first endeavour was to make sure that I was dealing with true elaioplasts. In the hairs upon the corolla of young flowers, where I first observed these bodies, they occur as more or less spherical, highly refractive, granular structures usually somewhat larger than the nucleus, and in most cases lying singly in a cell, although two or even more such bodies were occasionally met with.

Their reactions were found to be as follows :-

I. Heated gently upon the slide (whilst lying in a physiological salt solution), drops of oil are exuded from their surface (Fig. I3).

2. Osmic acid (as this occurs in Flemming's stronger solution) turns them black or brown.

3. Potassium bichromate after twenty-four hours' action leaves them quite colourless, but causes the extrusion of oil globules as in $\mathrm{I}$.

4. Alkannin solution in 60 per cent. alcohol colours the bodies deeply red.

5. Iodine (in KI) colours them brown and causes the extrusion of oilglobules (Fig. I2).

6. Absolute alcohol dissolves out the oil from their interior and leaves them vacuolated.

7. In strong $\mathrm{HNO}_{3}$ (warmed), followed by $\mathrm{NH}_{3}$, they give the Xanthoproteic reaction (viz., deep yellow coloration).

8. Glacial acetic acid after twenty-four hours' action causes great extrusion of oil drops but no solution.

9. Io per cent. $\mathrm{KOH}$. after twenty-four hours' action dissolves neither stroma nor oil drops.

These reactions, combined with their general appearance, show that the bodies occurring in the hairs of Gaillardia are in all respects similar to the elaioplasts described by previous authors.

In very young hairs from capitula which were still quite small and

1 Gaillardia Lorenziana is a German variety of $G$. picta, which itself appears to be only a garden variety of $G$. pulchella. I have not yet had an opportunity of examining any other form or species of Gaillardia except the one mentioned above. 
immature and entirely enclosed within the involucral bracts, no elaioplasts were yet to be seen. The cell contained a nucleus and cytoplasm which partly formed a peripheral layer and partly extended in strands and bars through the cell cavity (Figs. I and 2). Embedded in the cytoplasm was a number of small, highly refractive grains which had all the appearances of ordinary leucoplasts. That these refractive grains are really leucoplasts is confirmed by two facts.

Firstly, the resemblance between the unquestionable, starch-forming leucoplasts occurring, for example, in the hairs which cover the very young leaves, and the highly refractive grains contained in the corolla-hairs, is complete, although starch is not found in the latter under the usual conditions of growth.

Secondly, if the enveloping bracts be removed from a young inflorescence without detaching it from the parent plant, and the corolla-hairs exposed to a strong insolation, starch can be seen to have developed in some of these refractive grains.

For these reasons I believe the highly refractive grains occurring in the cells of the corolla-hairs to be leucoplasts, some of which, however, may have lost the power of starch-formation.

In somewhat older hairs these plastids, a number of which show signs of undergoing degeneration, tend to aggregate together at one or more spots within the cell. Not infrequently this aggregation of the plastids is in the neighbourhood of the nucleus, but in many instances it is found to occur at other regions of the cell (Figs. 3 and 4 ).

At first the aggregation of the refractive grains is a very loose one, but it gradually grows closer and closer (Fig. 5) until the compact, highly refractive bodies are formed, which we have already recognized as elaioplasts (Figs. 6, 7, and 8). The elaioplasts in the corolla-hairs of Gaillardia are, therefore, formed by the aggregation of plastids and their degeneration products at one or more spots in the cell. Within the elaioplast the plastids soon appear to undergo further degeneration with the production of an oily material. That Zimmermann should find a close similarity between the oil of the elaioplasts studied by him and the oil obtained from plastids is no longer surprising.

All the plastids of the cell have not clumped together within the elaioplast. A certain proportion still remain scattered through the cell (Fig. 7).

For some time there is little alteration within the cell. The conspicuous elaioplast may lie in almost any part of the cell, but often it takes up a position near the nucleus. In some instances it entirely envelops the nucleus, as I have represented in Fig. 8.

In much older hairs we find the elaioplast undergoing a change. Its outline becomes less regular, and in some cases it becomes drawn out 
and elongated in form (Fig. 9). In favourable cases one can see that the faintly yellowish drops or granules of which it now chiefly consists are becoming detached from the periphery of the main body of the elaioplast, and that these drops or granules are gradually scattered through the cell cavity (Fig. IO). Here they deepen their yellow tint, and in association with the red pigment developed in the cell-sap they produce the yellow, orange, or red coloration of the mature corolla-hairs, according as the one or the other pigmenting material predominates (Fig. II).

The constituent plastids of these elaioplasts, therefore, undergo quite a similar series of changes as the chlorophyll grains in autumn leaves, which were first described in detail by Sachs in 1863 (10), or in ripening fruits, also studied by Sachs (1865). By the time the hairs are fully matured the elaioplast has entirely resolved itself into the scattered yellow pigment of the cell.

The corolla-hairs are not the only place in which elaioplasts occur in Gaillardia. They are also to be found in the stigmatic hairs, or in the more internal cells of the stigma and of the style, in the vegetative cells of the anther, and in the cells of the young pappus (calyx).

I sought for them in vain in the root-hairs or in the tissues of the root, in the leaf and the hairs which cover it, in the stem, and its clothing of hairs.

After I had completed my observations on the elaioplasts in the corolla-hairs, and drawn from them the conclusions which I have expressed above, I received a beautiful confirmation of the correctness of these views from the study of the elaioplasts in the other floral regions of Gaillardia.

In the cells of the connective of the young stamen, bodies occur which resemble the elaioplasts of the corolla-hairs in every respect except that they are coloured more or less deeply green. They are mostly spherical, although sometimes elongated in shape (Fig. I4). Moreover, in neighbouring cells of the connective we find every transition between deeply green bodies of this description, and others which are almost colourless and differ in no way from the elaioplasts of the corolla-hairs. On the addition of Iodine solution the occurrence of starch within the green bodies is readily demonstrated (Fig. 12). After remaining in the Iodine solution for some hours these intensely black-stained bodies form a most conspicuous feature in the otherwise yellow cells.

The appearance and reactions of these green bodies, no less than the transitions which occur between them and the ordinary elaioplasts, leave no doubt that they also are elaioplasts which contain chlorophyll, and which have retained the power of starch-formation. The cells of the young style and stigma also possess green, starch-producing elaioplasts.

Another very interesting case of green elaioplasts is furnished by the cells of the flattened basal plates or wings of the young pappus. In 
many of these cells scattered chloroplasts occur, arranged as in ordinary assimilating tissue (Fig. I5). These chloroplasts are large, and many of them contain droplets of an apparently oily nature embedded within their substance. Probably these oil-drops mark the first stage of degeneration, although the power of starch-formation has not yet been lost. I was at first inclined to believe that the oily drops within these chlorophyll corpuscles represented the normal grana of these bodies developed to a rather unusual extent. The fact, however, that the chloroplasts of the other organs of Gaillardia (e. g., of the leaf) do not show any distinct grana of this kind, coupled with the further fact that the chlorophyll bodies of the pappus soon show undoubted signs of degeneration, has led me to conclude that the oil-drops are associated with the degradation of these chloroplasts.

In other cells of the pappus-plates the chlorophyll corpuscles tend to hang, more or less loosely, together. In yet other cells the aggregation of the chloroplasts is closer, although the outlines of each separate plastid is still maintained (Fig. I6). A further step in this aggregation of the chlorophyll bodies is seen in other, neighbouring cells in which they become so closely clumped together that the outlines of the individual chloroplasts can no longer be distinguished, and we obtain a typical green elaioplast in which the oil-drops of the plastids produce the finely granular appearance characteristic of these structures.

All these stages may be observed in adjoining cells of one and the same pappus-plate. They are best studied at about the time when the young pollen-grains are still without a membrane of their own and are enveloped in the special-wall (special mother-cell stage).

In older pappus-plates the green colour of the elaioplasts gives place to yellow, and other degeneration processes become evident.

Now that the development of the elaioplast has been followed in at least one species we are in a better position to compare this body with the oil-bodies of Hepaticae. Wakker evidently believed in the identity of the two structures, whilst other authors--such as Von Küster (11)-held an opposite opinion. On comparing what has been written above regarding the elaioplasts of Gaillardia with Garjeanne's careful account of the development of the oil-bodies of several Jungermanniales, it will be seen that the two structures have a very different origin. In the latter the oil-bodies arise as vacuoles in the cytoplasm, whilst we have seen that the elaioplasts of Gaillardia are formed by the aggregation of plastids and their degeneration products. Whilst, therefore, we cannot draw general conclusions until other species have been examined more fully, we may say that the developmental history of the elaioplasts of Gaillardia is essentially different from that of the oil-bodies of the Hepaticae.

External conditions seem to exert very little influence on the appearance of the elaioplasts. 
I have kept the young capitula in total darkness for several (3-6) days without altering the development or structure of the elaioplasts of the corollahairs in the least.

The only deviation which I have ever found in the behaviour of the plastids of the corolla-hairs occurred in a very young capitulum from which the protecting bracts had been dissected away so that the tiny flower-buds were exposed to the full effect of the light.

Here the aggregation of the plastids into elaioplasts had been retarded in a number of cells.

The clumping together of the plastids of a cell into a more or less close mass is by no means an unusual occurrence. Kraus (12) many years ago described the effect of cold upon the chlorophyll-grains of winter leaves. Here these bodies were found to have passed from the walls to the interior of the cells and were there aggregated in clumps. Charles Darwin (13), in I882, observed a very close massing of the chloroplasts in the cells of certain insectivorous plants under the influence of ammonium carbonate (a solution of 4-7 parts of ammonium carbonate in $\mathrm{I}, 000$ parts water).

The work of Stahl (14), as well as of others, has shown that an irregular aggregation of chloroplasts is produced under the influence of intense illumination.

Pfeffer (15) mentions that similar results are induced by injuries and various mechanical agencies.

The close massing of the plastids into compact elaioplasts is most probably connected with their degeneration, and may very likely be compared to the aggregation of these bodies produced by the injurious agencies enumerated above. That the elaioplasts have any particular function to perform which is of direct significance to the life of the cell is most unlikely.

A secondary use for the degeneration products of the plastids-massed into elaioplasts - certainly does occur in the case of the corolla-hairs of Gaillardia, for here they give rise to the yellow pigment which forms an important part of the attractive apparatus of the mature flower.

In other situations, however, the elaioplasts seem to disappear, without having even this secondary biological significance.

It will be interesting to examine the Monocotyledonous elaioplasts again more closely in the light of what has been learnt of these bodies in Gaillardia, to see whether they possess the same nature and history. I hope to obtain material for this purpose during the next season.

In conclusion, I must express my indebtedness to a Government grant for assistance in carrying out this research. 


\section{SUMMARY.}

I. Elaioplasts which hitherto had only been met with in Monocotyledons (and Psilotum) have now been found to occur in a Dicotyledon-Gaillardia.

2. The elaioplasts occurring in the corolla-hairs of Gaillardia are found to agree in their appearance and in their reactions with the elaioplasts described by Wakker and Zimmermann in Monocotyledons.

3. They have been found in the corolla-hairs, the pappus, the connective of the stamens, the style and the stigma of Gaillardia. They are absent from the tissues of the stem, the root, and the leaf of this plant.

4. They are formed by the aggregation of plastids and their degeneration products at one or more spots in the cell.

5. In the corolla-hairs of Gaillardia they give rise to the oily, yellow pigment which, in association with the red cell-sap, gives the mature hairs of the flower their characteristic colour.

6. The elaioplasts occurring in the stamens and in the style and stigma of Gaillardia agree in all respects with those of the corolla-hairs except that they are coloured green with chlorophyll, and can form starch within their substance. In neighbouring cells of these tissues all transitions occur. between elaioplasts, which are coloured brightly green, and those which are almost colourless like those of the corolla-hairs.

7. In the tissues of the young pappus every transition can be found in neighbouring cells between those which contain scattered chloroplasts entirely free from one another, and those in which the chloroplasts have clumped together to form a green mass identical with the green elaioplast of the stamen or the stigma.

8. The elaioplasts of Gaillardia (and probably of the Monocotyledons also) differ essentially in their development from the oil-bodies of the liverworts.

9. External conditions were found to exert very little influence upon the appearance of the elaioplast, although rather strong, direct illumination seemed in one case to have somewhat retarded the aggregation of the plastids.

IO. The close massing of the plastids into compact elaioplasts is probably connected with their degeneration, and may be compared to the aggregation of the plastids under the influence of various (mostly injurious) agencies described by several previous writers.

II. It is most unlikely that the elaioplasts perform any function of direct importance to the life of the plant, although they may in some cases (corolla-hairs of Gaillardia) serve a secondary, biological purpose. 


\title{
REFERENCES TO LITERATURE.
}

1. Wakker, J. H.: Studien über die Inhaltskörper der Pflanzenzelle. Pringsh. Jahrb. f. wiss Bot., xix, I888, p. $4^{23}$, \&c.

2. Zimmermann, A.: Ueber die Elaioplasten. Beiträge z. Morphol. u. Physiol. d. Pflanzenzelle, I 893 , p. $185, \&$ c.

3. RACIBORSKI, M. : Ueber d. Entwicklungsgesch. d. Elaioplasten d. Liliaceen. Anzeig. d. Akad. d. Wiss. in Krakau, I893, p. 259. I was unable to obtain this paper and quote from the abstract in Bot. Centralbl., 1vii, 1894, p. 305.

4. Pfeffer, W.: Die Oelkörper der Lebermoose. Flora, 1874, p. 2, \&c.

5. Garjeanne, M. J. : Die Oelkörper der Jungermanniales. Flora, xcii, 1903, p. 457, \&c.

6. RAdLKofer, L.: Zur Klärung von Theophrasta und der Theophrasteen. Sitzungsber. d. math.-physik. Kl. d. K. B. Akad. d. Wiss. zu München, xix, I889, p. 221.

7. — Ueber die Gliederung d. Familie d. Sapindaceen. Ib., xx, I890, p. I05.

8. Monteverde, N. A.: Ueber die Ablagerung von Calcium- und Magnesium-Oxalate in d. Pflanze. Petersburg, I889.

9. Solereder, H.: Studien über die Tribus der Gaertnereen. Ber. d. Deutsch. Bot. Gesellsch., I $890, \mathrm{p} .7 \mathrm{I}$.

10. SAchs, J. von : Entleerung der Blätter im Herbst. Flora, I863, p. 200.

11. Küster, von: Die Oelkörper der Lebermoose u. ihr Verhältniss zu den Elaioplasten. Basel, 1894.

12. Kraus, G. : Bot. Zeit., I874, p. 406.

13. Darwin, C. : The action of Carbonate of Ammonia on Chlorophyll Bodies. Journ. Linn. Soc., xix, I882, p. 262 .

14. Stahl, E. : Ueber den Einfluss d. Richtung u. Stärke d. Beleuchtung auf einige Bewegungsersch. im Pflanzenreiche. Bot. Zeit., I880, p. 340.

15. Pfeffer, W.: Physiology of Plants (Eng. trans.), iii, I906, p. 329.

\section{EXPLANATION OF FIGURES IN PLATE IV.}

\author{
Illustrating Mr. Beer's Paper on Elaioplasts.
}

All the figures refer to tissues of Gaillaraia Lorenziana. Preparations examined and drawn in .6 per cent. $\mathrm{NaCl}$ solution unless otherwise stated.

Fig. I. Very young cell of corolla-hair before elaioplasts have developed. Leucoplasts distributed in the cytoplasm. $\times 1075$.

Fig. 2. Apex of another corolla-hair showing scattered leucoplasts. $\quad \times 650$.

Fig. 3. Young cell of corolla-hair showing an early stage in the aggregation of plastids. $\quad \times 6_{5} 0$.

Fig. 4. Corolla-hair showing a stage in aggregation of plastids. $\times 6_{50}$.

Fig. 5. Corolla-hair with later stage of elaioplast development. $\times 6_{50}$.

Figs. $6,7,8$. Elaioplast completely developed in corolla-hairs. $\times 6_{5}$.

Fig. 9. Cell from older corolla-hair. Elaioplast elongated and showing first indication of disintegrating. $\times 6_{5}$. 
Fig. Io. Later stage; substance of elaioplast becoming distributed through the cell. $\quad \times 600$.

Fig. II. Mature corolla-hair. Yellow pigment-material derived from elaioplast completely distributed through the cell. $\times 650$.

Fig. I 2. Green elaioplast from anther after two days in dilute Iodine solution. Oil-drops have been exuded at the surface. Starch (shown in the figure as black grains) contained in the yellowstained matrix. $\times 600$.

Fig. 13. Elaioplast from corolla-hair in .6 per cent. $\mathrm{NaCl}$ after gently warming on slide over spirit-lamp. $\times 650$.

Figs. I5 and I6. Two neighbouring cells from plate of pappus. In Fig. I5 the chloroplasts are scattered, whilst in Fig. 16 they are massed into a loose clump. Note oil-drops within the chloroplasts (represented as black dots). $\times$ about 600 . 
Annals of Botany:

Vol.XXIII, Pl.IV.
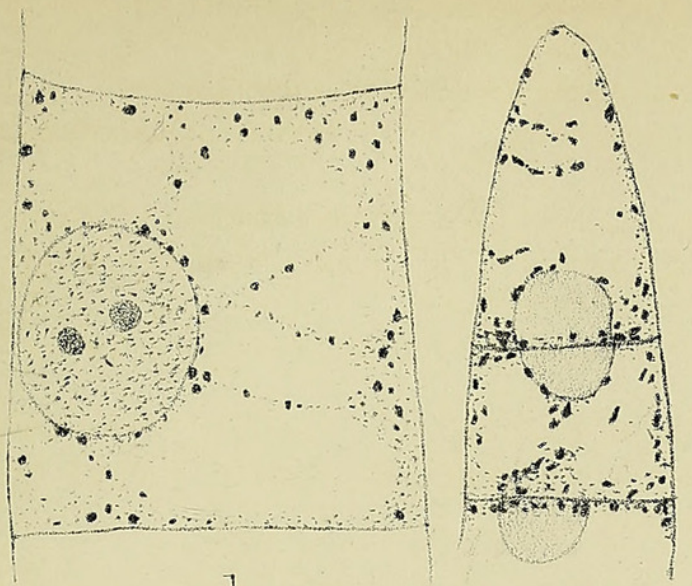

1.
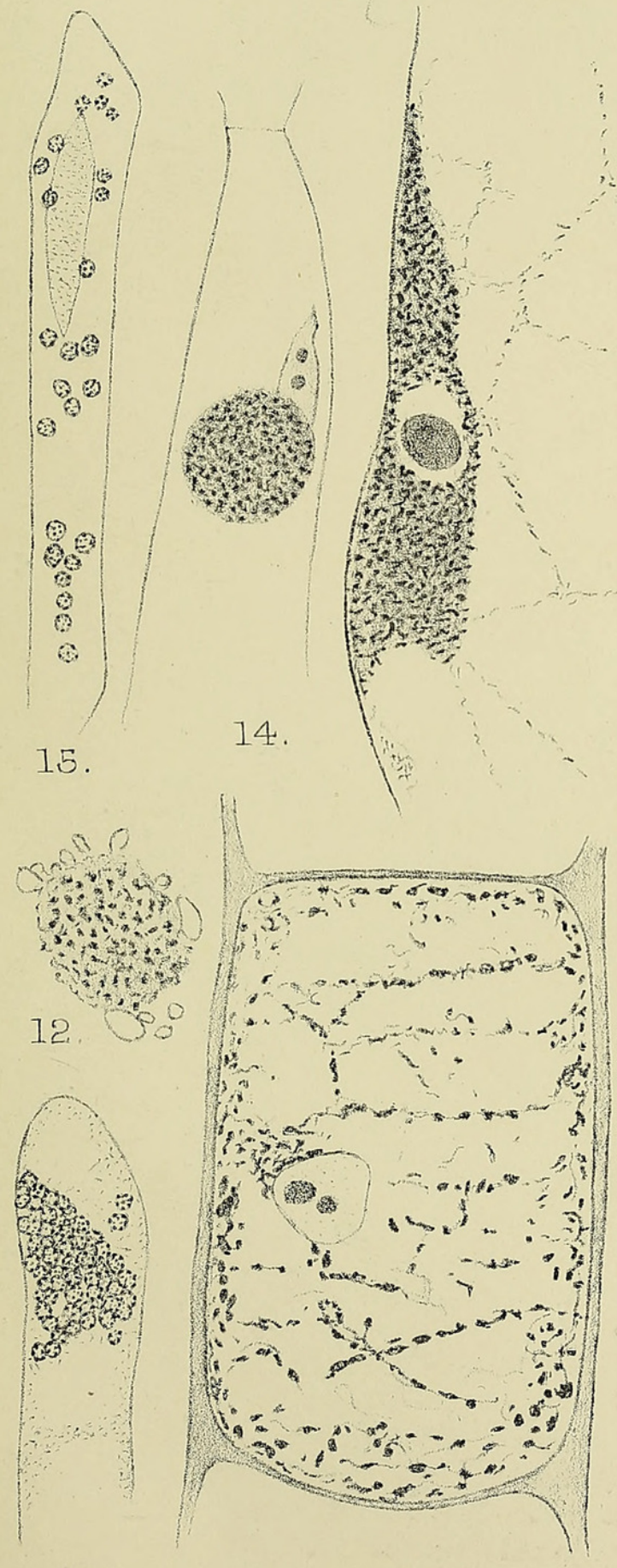

16.
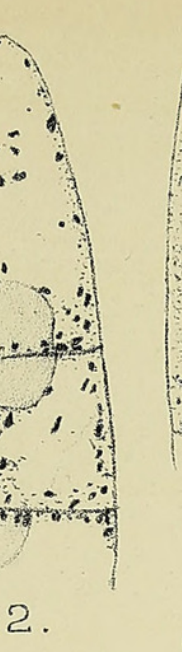
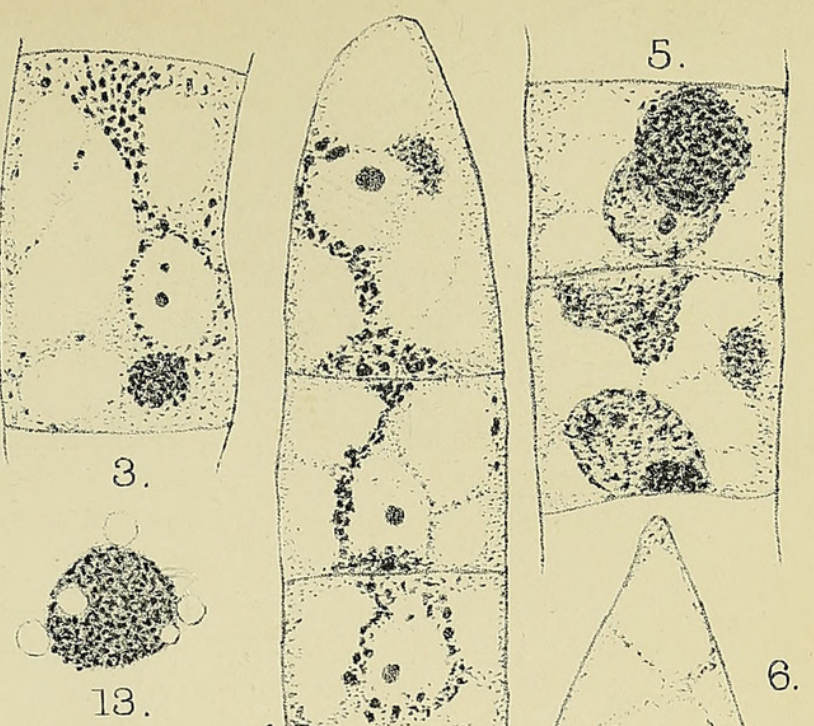

9.
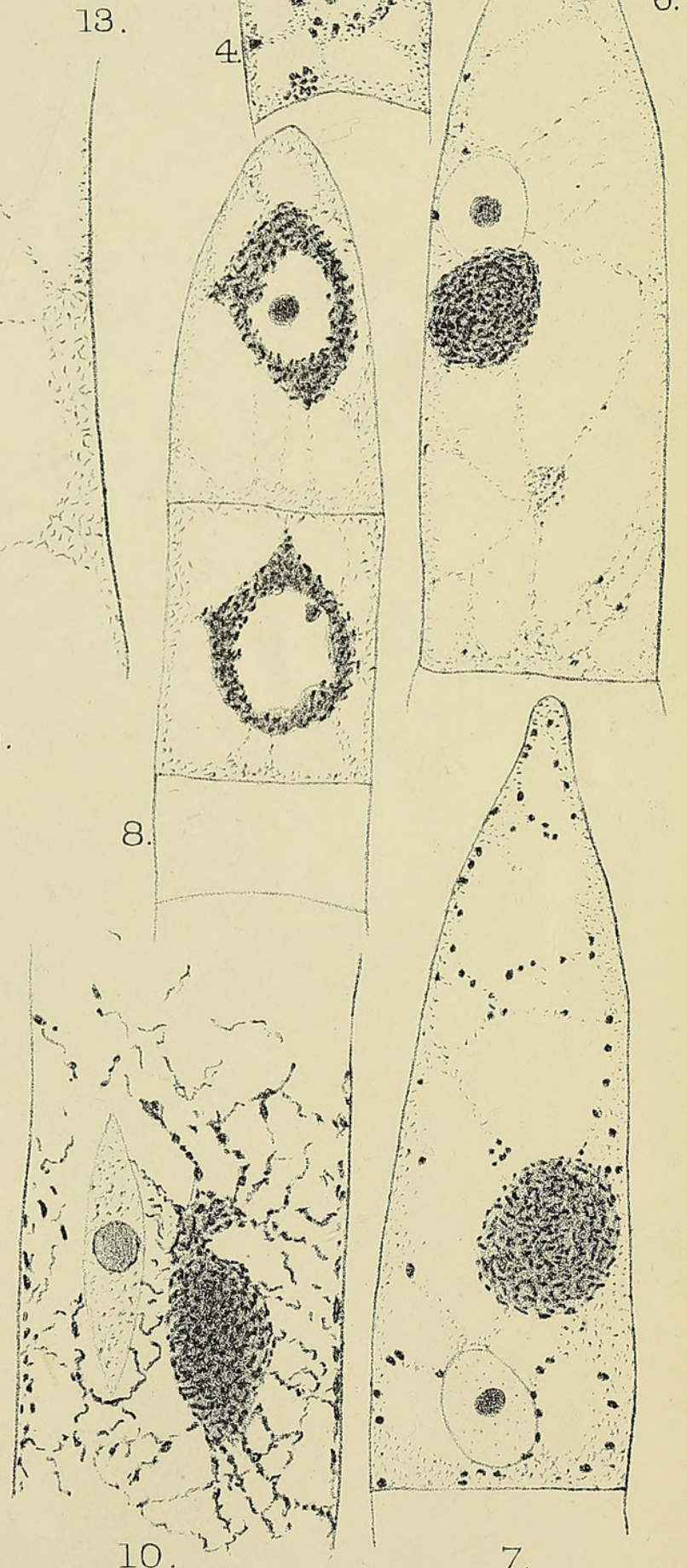


\section{$2 \mathrm{BHL}$ Biodiversity Heritage Library}

Beer, Rudolf. 1909. "On elaioplasts." Annals of botany 23, 63-72. https://doi.org/10.1093/oxfordjournals.aob.a089207.

View This Item Online: https://www.biodiversitylibrary.org/item/236540

DOI: https://doi.org/10.1093/oxfordjournals.aob.a089207

Permalink: https://www.biodiversitylibrary.org/partpdf/318939

\section{Holding Institution}

Smithsonian Libraries

\section{Sponsored by}

Biodiversity Heritage Library

\section{Copyright \& Reuse}

Copyright Status: Not in copyright. The BHL knows of no copyright restrictions on this item.

This document was created from content at the Biodiversity Heritage Library, the world's largest open access digital library for biodiversity literature and archives. Visit BHL at https://www.biodiversitylibrary.org. 